\title{
ANALYSIS OF PLAG1 EXPRESSION IN PLEOMORPHIC ADENOMA AND CARCINOMA EX PLEOMORPHIC ADENOMA
}

Beatriz Samara de Brito (IC), Natália Giovanelli (IC), Harim Tavares dos Santos (PG), Erika Egal (PG), Prof. Dr. Oslei Paes de Almeida (PQ), Prof. Dr. Luiz Paulo Kowalski (PQ), Profa. Dra. Albina Messias de Almeida Altemani (PQ), Dra. Fernanda Viviane Mariano (PQ)

\begin{abstract}
Pleomorphic adenoma (PA) is the most common salivary gland neoplasm, corresponding to about $60 \%$ of all neoplasms. Although most cases are surgically removed by radical resection, recurrences may occur even after several decades and in some cases malignant transformation may still occur of a pre-existing PA causing the carcinoma ex pleomorphic adenoma (CXPA). CXPA, although relatively rare, reserve a poor prognosis and it has an aggressive clinical course. Strong correlation has been described between both neoplasia and the proto-oncogene PLAG1 (Pleomorphic Adenoma Gene 1) which leads to production of a protein that positively regulates several growth factors genes. The PLAG1 expression analysis in both tumors will help in the confirmation this marker for the diagnosis of PA and CXPA, besides of contribute to better understanding of carcinogenesis of CXPA.
\end{abstract}

Key words: pleomorphic adenoma, carcinoma ex pleomorphic adenoma, PLAG1

\section{Introduction}

The proto-oncogene PLAG1 is located at $8 \mathrm{q} 12$, its activation is a result of chromosomal aberrations and leads to the production of a protein. Overexpression of PLAG1 protein is often described in PA and supposed maintenance to CXPA. Because of the rarity of CXPA, we attempt to identify biological carcinogenesis and assessment markers are still inconclusive. The objective of this study was to evaluate the maintenance PLAG1 expression by immunohistochemistry in a series of PA and CXPA of different histopathological subtypes and in different stages of carcinogenesis.

\section{Results and Discussion}

Forty PA and forty-one CXPA (twenty-two CXPA had residual PA) were analyzed. When the proportion of positive cells was $>10 \%$ the case was judged to be positive. The proportion of positive neoplastic cells was assessed according to a two-tiered scale: $>10 \%$ to $50 \%$, and $>50 \%$ positive cells. Thirty PA (75\%) had $>50 \%$ of positive cells, six (15\%) had between $10 \%$ and $50 \%$ of positive cells and four (10\%) were negative. Twelve residual PA (54\%) had $>50 \%$ of positive cells; five (23\%) had between $10 \%$ and $50 \%$ of positive cells; five (23\%) were negative. Seven CXPA (17\%) had $>50 \%$ of positive cells; five $(12 \%)$ had between $10 \%$ and $50 \%$ of positive cells; twenty-nine $(70 \%)$ were negative. Cases of CXPA, eight $(20 \%)$ they have been classified as intracapsular, nine (22\%) as minimally invasive and twenty-four (58\%) as frankly invasive and its positivity in the PLAG1 is shown in Table 1.
Table 1. Positivity of PLAG1 in CXPA reaction according to the degree of capsular invasion

\begin{tabular}{|l|l|l|l|l|}
\hline $\begin{array}{l}\text { Degree of } \\
\text { invasion }\end{array}$ & $\begin{array}{l}\mathbf{1 0 \%} \text { a } \\
\mathbf{5 0 \%}\end{array}$ & $<\mathbf{1 0 \%}$ & Zero & Total \\
\hline Intracapsular & $3(37 \%)$ & $3(37 \%)$ & $2(25 \%)$ & 8 \\
\hline $\begin{array}{l}\text { Minimally } \\
\text { invasive }\end{array}$ & 0 & $3(33 \%)$ & $6(67 \%)$ & 9 \\
\hline $\begin{array}{l}\text { Frankly } \\
\text { invasive }\end{array}$ & $6(25 \%)$ & $5(21 \%)$ & $13(54 \%)$ & 24 \\
\hline
\end{tabular}

\section{Conclusions}

PLAG1 is modulator gene in PA, but its expression is lost when the PA undergoes malignant transformation. Possibly the carcinoma acquires activation of other pathways independent of PLAG1 function.

\section{Acknowledgement}

We thank FAPESP (Process 2014 / 18312-1 and Process 2011/23366-5) for the contribution to the development of our research.

\footnotetext{
BAHRAMI, Armita et al. PLAG1 Alteration in Carcinoma Ex Pleomorphic Adenoma: Immunohistochemical and Fluorescence In Situ Hybridization Studies of 22 Cases. Head and Neck Pathol, v.6, p.328-335, 2012.

2 GNEEP DR, Brandwein-Gensler, El-Naggar AK. Carcinoma ex pleomorphic adenoma. In: Barnes L, Eveson JW, Reichart P, editors. Pathology and genetics of head and neck tumors. World Health Organization Classification of Tumors. Lyon: IARC Press, p. 242 243, 2005.

${ }^{3}$ WEINREB, Ilan. Translocation-associated Salivary Gland Tumors: A Review and Update. Adv Anatomic Pathology, v. 20, p. 367-377, 2013.
} 